\title{
Reproductive characteristics are associated with gene-specific promoter methylation status in breast cancer
}

\author{
Lauren E. McCullough ${ }^{1 *}$ (D), Lindsay J. Collin ${ }^{1}$, Kathleen Conway², Alexandra J. White ${ }^{3}$, Yoon Hee Cho ${ }^{4}$, \\ Sumitra Shantakumar ${ }^{5}$, Mary Beth Terry ${ }^{6}$, Susan L. Teitelbaum9, Alfred I. Neugut ${ }^{6,7}$, Regina M. Santella ${ }^{8}$, \\ Jia Chen ${ }^{6,10,11}$ and Marilie D. Gammon ${ }^{2}$
}

\begin{abstract}
Background: Reproductive characteristics are well-established risk factors for breast cancer, but the underlying mechanisms are not fully resolved. We hypothesized that altered DNA methylation, measured in tumor tissue, could act in concert with reproductive factors to impact breast carcinogenesis.

Methods: Among a population-based sample of women newly diagnosed with first primary breast cancer, reproductive history was assessed using a life-course calendar approach in an interviewer-administered questionnaire. Methylation-specific polymerase chain reaction and Methyl Light assays were used to assess gene promotor methylation status (methylated vs. unmethylated) for 13 breast cancer-related genes in archived breast tumor tissue. We used case-case unconditional logistic regression to estimate adjusted odds ratios (ORs) and 95\% confidence intervals (Cls) for associations with age at menarche and parity (among 855 women), and age at first birth and lactation (among a subset of 736 parous women) in association with methylation status.

Results: Age at first birth $>27$ years, compared with $<23$ years, was associated with lower odds of methylation of CDH1 (OR $=0.44,95 \% \mathrm{Cl}=0.20-0.99)$ and TWIST1 $(\mathrm{OR}=0.48,95 \% \mathrm{Cl}=0.28-0.82)$, and higher odds of methylation of BRCA1 (OR $=1.63,95 \% \mathrm{Cl}=1.14-2.35)$. Any vs. no lactation was associated with higher odds of methylation of the $P G R$ gene promoter $(\mathrm{OR}=1.59,95 \% \mathrm{Cl}=1.01-2.49)$. No associations were noted for parity and methylation in any of the genes assayed.

Conclusions: Our findings indicate that age at first birth, lactation and, perhaps age at menarche, are associated with gene promoter methylation in breast cancer, and should be confirmed in larger studies with robust gene coverage.
\end{abstract}

Keywords: Breast Cancer, Epidemiology, Epigenetics, Reproductive characteristics, DNA methylation

\section{Background}

Breast development is a complex biological process that occurs in several phases across the life-course; initiated during the embryonic period, continuing through puberty, with terminal differentiation following first birth and lactation. [1] Consistent with mammogenesis, there is accumulating evidence that early life characteristics play an important role in the etiology of breast carcinogenesis. [2] Reproductive characteristics that contribute to cumulative

\footnotetext{
* Correspondence: lauren.mccullough@emory.edu

'Department of Epidemiology, Emory University, Atlanta, GA 30322, USA

Full list of author information is available at the end of the article
}

hormonal exposure, such as age at menarche, parity, age at first birth, and lactation, are well-established risk factors for breast cancer. [3] However, the mechanisms underlying these associations remain unresolved.

We hypothesized that reproductive characteristics could potentially be differentially associated with breast cancer based on epigenetic alterations in the tumor. Aberrant DNA methylation, an epigenetic modification, can modify gene expression to impact breast carcinogenesis. [4, 5] For example, promoter hypermethylation of tumor suppressor genes has been associated with clinical and pathological factors of breast cancer, as well as mortality in a population-

(c) The Author(s). 2019 Open Access This article is distributed under the terms of the Creative Commons Attribution 4.0 International License (http://creativecommons.org/licenses/by/4.0/), which permits unrestricted use, distribution, and 
based sample. [6] DNA methylation alterations are associated with environmental and lifestyle factors and could be a biologic mechanism for disease. [7] Tobacco smoke, nutrient intake, and air pollution exposure are all associated with epigenetic modification through gene promoter methylation. [8] The association between epigenetic modifications and reproductive characteristics has received limited attention. In one previous study of 803 archived breast tumors, no differences in promoter methylation of E-cadherin (CDH1), CDKN2A, or RAR- $\beta 2$ by age at menarche or age at first birth were noted. [9] However, this previous research was limited to only three breast cancer-related genes and did not consider associations with parity or lactation.

To address our hypothesis, we examined whether four reproductive characteristics (age at menarche, age at first birth, lactation, and parity) were associated with promoter methylation status in a panel of 13-breast cancer-related genes measured in archived tumor tissue of a population-based sample of women with newly diagnosed breast cancer.

\section{Methods}

We utilized resources from case women enrolled in the Long Island Breast Cancer Study Project (LIBCSP), a population-based study. [10] Institutional Review Board approval was obtained by all participating institutions (Columbia University, University of North Carolina Chapel Hill, and Emory University).

\section{Study population}

Study participants were residents of Nassau and Suffolk counties, Long Island, New York (NY). Eligible case women were diagnosed with first primary breast cancer between August 1, 1996 and July 31, 1997 identified using rapid case ascertainment via daily or weekly contact with pathology departments of all 28 hospitals on Long Island, and three tertiary care hospitals in NY City. [10] At the time of diagnosis, women were aged $20-98$ years $(67 \%$ postmenopausal) and primarily white (94\%). [10]

\section{Reproductive and covariate assessment}

Interviews for most participants occurred within 3 months of diagnosis (before completion of the first course of treatment) [10] and were completed for $82.1 \%$ $(N=1508)$ of eligible women. Written informed consent was obtained from all women prior to study interview.

Reproductive characteristics (occurring prior to the date of diagnosis) were assessed as part of the 100-min, in-home, interviewer-administered questionnaire. To aid recall, a month-by-month calendar approach [11] was used to record reproductive factors in the context of major life events. Age at menarche ( $\leq 12$ vs. $>12$ years of age), age at first birth among parous women $(<23,23-27,>27$ years of age), lactation practices among parous women (ever vs never), and parity (nulliparous vs parous), were assessed in these analyses. Category cut points were based on previous literature [12] and optimization of LIBCSP cell counts.

Women were additionally asked about their: demographic characteristics; lifestyle, environmental, and medical histories; family history of breast cancer; as well as use of exogenous hormones. [10]

\section{Gene-specific promoter DNA methylation assessment}

Archived pathology blocks were obtained from the participating hospitals for $962(63.8 \%)$ case participants; [13] tumor tissue was available for 855 (56.7\%) women. As previously described, promoter methylation status was measured in tumor tissue for a panel of 13 breast cancer-related genes [adenomatous polyposis coli $(A P C)$, breast cancer 1, early onset (BRCA1), cyclin D2 (CCND2), E-Cadherin ( $C D H 1)$, death-associated protein kinase 1 (DAPK1), estrogen receptor 1 (ESR1), glutathione S-transferase pi 1 (GSTP1), secretoglobin, family 3A, member 1 (HIN1), cyclin-dependent kinase inhibitor 2A $(C D K N 2 A)$, progesterone receptor $(P G R)$, retinoic acid receptor beta $(R A R \beta)$, Ras association domain family member 1 (RASSF1A) and twist homolog 1 (TWIST1)]. [14] While a broader panel could be hypothesis generating, given the sample size, a more focused panel of genes reduces chances of type II error. These genes were selected based on their putative functions and their promoter regions are frequently methylated in breast tumor tissues. [14]

For study participants with available tissue blocks, the paraffin blocks were used to generate $15 \times 5$ micron and $100 \mu \mathrm{m}$ this slides, which were isolated via microdissection. Tumour DNA was isolated by adding $30 \mathrm{ul}$ of proteinase K-digestion buffer and with overnight incubation. After DNA extraction from the archived tumor tissue, [15] gene-specific promoter methylation status was assessed for 13 genes. [14, 16] Promoter methylation of ESR1, PGR and BRCA1 was determined by methylationspecific (MSP) polymerase chain reaction (PCR), as described previously. $[15,17]$ For select genes (ESR1, PGR and BRCA1), the methylation status was determined by whether PCR product was obtained using methylationspecific primers-thus, are dichotomous variables (methylated vs. unmethylated). The quantitative MethyLight assay was used to determine methylation status of the remaining 10 genes. Bisulfite-converted genomic DNA was amplified using a fluorescence-based, real-time quantitative PCR, which yields a continuous measure of methylation. [18] Percentage of methylation was calculated by the $2^{-\Delta \Delta C T}$ method, where $\Delta \Delta C_{T}=\left(C_{T, T a r g e t}-C_{T, A c t i n}\right)_{s a m}$ ple $-\left(C_{T, \text { Target }}-C_{T, A c t i n}\right)_{\text {fully methylated DNA }}[19]$ and multiplying by 100 . For consistency with previous published reports by our study team [14] and others, we dichotomized ( $<4 \%, \geq 4 \%$ methylated) the resulting values, [20] as it has been previously shown to distinguish between 
malignant and normal tissues and is indicative of repressed gene expression. [21] The numbers of assayed samples and corresponding methylation frequencies for the selected genes are summarized in Xu et al. [14] Insufficient DNA, primarily due to small tumor size, was the primary main reason for missing methylation data.

\section{Hormone receptor (HR) subtype assessment}

Breast cancer subtype for the first primary was defined by estrogen/progesterone receptor status (ER/PR) obtained from the medical record, and was available for $65.6 \%$ of cases $(N=990)$. [10] ER/PR and tumor methylation status were available for $63.3 \%(N=627)$ of our participants. Given that reproductive characteristics have been etiologically linked to breast cancer primarily through an estrogen pathway, we did not consider human epidermal growth factor receptor 2 (HER2) in our subtype assessment.

\section{Statistical methods}

All statistical analyses were conducted using SAS 9.4 (Cary, $\mathrm{NC}$ ) using a two sided $p$-value $<0.05$ as the cutoff for statistical significance. Employing a case-case approach, we assessed whether four reproductive characteristics (considered independently) were associated with methylation in tumor tissue. We used unconditional logistic regression [22] to estimate odds ratios (ORs), and corresponding 95\% confidence intervals (CIs) for each of the 13 markers, with case groups characterized by tumor methylation status (methylated vs. unmethylated). For age at menarche and parity, models included all cases with tumor tissue available $(N=855)$; for age at first birth and lactation, models were restricted to parous women only $(N=736)$. The case-case OR estimates the likelihood of a case possessing a methylated gene-promoter given their specific reproductive characteristic. ORs greater than 1 indicate higher odds of methylation, while ORs less than 1 indicate lower odds of methylation.

Given reproductive characteristics likely influence breast carcinogenesis through an estrogen pathway, [23, 24] we explored whether the association between reproductive characteristics and hormone receptor status (ER + PR+ vs. all others: ER-PR-, ER + PR-, ER-PR+) varied by gene-specific promoter methylation. We used unconditional logistic regression to estimate ORs (95\% CIs) where the OR estimates the likelihood of an ER + PR+ case, given both gene methylation and reproductive characteristics. Using a likelihood ratio test, we assessed evidence for multiplicative interaction-comparing multivariable models with and without cross-product terms to represent the interaction between reproductive characteristics and a gene-specific methylation marker $(\alpha=0.05)$. A significant interaction would suggest that the odds of a case possessing the ER + $\mathrm{PR}+$ breast cancer subtype, given the reproductive characteristic, are statistically different across strata of gene-specific methylation.

Confounders were identified based on the known epidemiology of breast cancer and analysis of causal diagrams (DAG). [25] For all models, DAG-identified confounders included: race (white/black/other); family history of breast cancer (yes/no); and history of benign breast disease (yes/no), and 5-year age group. Confounders were included in the model if their removal changed the effect estimate $>10 \%$. [26] Only 5-year age group remained in the final case-case models. We did not consider simultaneous adjustment of reproductive factors because they did not meet the causal structure of a confounder and, were highly correlated.

\section{Results}

The distribution of demographic and clinical/pathological characteristics among cases with any tumor methylation marker $(N=855)$ were similar to the corresponding distributions among all LIBCSP participants with breast cancer $(N=1508)$ (Table 1$)$.

Estimates for the associations between each of the four individual reproductive characteristics and the 13 genespecific methylation markers are shown in Tables 2-5. We observed an inverse association between age at menarche $\leq 12$ years (vs. > 12 years) and methylation of the BRCA1 promoter $(\mathrm{OR}=0.79, \quad 95 \% \quad \mathrm{CI}=0.60-1.04)$ (Table 2). Conversely, late age at first birth ( $>27$ years vs. $<23$ years) was associated with increased odds of methylation of BRCA1 (OR $=1.63,95 \% \mathrm{CI}=1.14-2.35)$ and lower odds of methylation at $C D H 1(\mathrm{OR}=0.44,95 \%$ $\mathrm{CI}=0.20-0.99)$ and TWIST1 (OR $=0.48,95 \% \mathrm{CI}=0.28$ 0.82 ) gene promoters (Table 3). Any vs. no lactation was associated with higher odds methylation of the PGR gene promoter $(\mathrm{OR}=1.59,95 \% \mathrm{CI}=1.01-2.49)$ (Table 4$)$. We observed no associations between parity and methylation of any of the 13 gene promoters (Table 5).

When we explored ER/PR status of breast cancer in addition to methylation status, early age at menarche was associated with low odds of $\mathrm{ER}+\mathrm{PR}+$ breast cancer in the presence of methylated RASSF $1 A(\mathrm{OR}=0.59 ; 95 \% \mathrm{CI}=$ $0.40-0.86$ ) (Additional file 1: Table S1), whereas the corresponding OR among women with unmethylated RASSF1A was $1.64(95 \% \mathrm{CI}=0.67-3.99)$ (multiplicative $p_{\text {interaction }}=$ 0.04) (Additional file 1: Table S1). BRCA1 methylation also modified the association between age at first birth and odds of $\mathrm{ER}+\mathrm{PR}+$ breast cancer (Additional file 1: Table S2. The odds of developing ER + PR+ breast cancer was $2.34(95 \% \mathrm{CI}=1.18-4.64)$ among women with late age at first birth (>27 years) and unmethylated BRCA1 promoters, whereas among women with methylated BRCA1 the OR was $0.88(95 \% \mathrm{CI}=0.51-1.51)$. We identified no differential associations by gene promoter 
Table 1 Distribution of reproductive and tumor characteristics among case women with any methylation marker ( $N=855)$ and among all case women in a population-based study $(N=1508)$, Long Island Breast Cancer Study Project

\begin{tabular}{|c|c|c|}
\hline & $\begin{array}{l}\text { Patients with any methylation marker } \\
\text { (Total } N=855) \\
N(\%)\end{array}$ & $\begin{array}{l}\text { All patients } \\
\text { (Total } N=1508) \\
N(\%)\end{array}$ \\
\hline \multicolumn{3}{|l|}{ Age at diagnosis } \\
\hline$<50$ years & $215(25.1)$ & $407(27.0)$ \\
\hline$\geq 50$ years & $640(74.9)$ & $1101(73.0)$ \\
\hline \multicolumn{3}{|l|}{ Menopausal status } \\
\hline premenopausal & $244(29.2)$ & $472(31.9)$ \\
\hline postmenopausal & $593(70.8)$ & $1006(68.1)$ \\
\hline missing & 18 & 30 \\
\hline \multicolumn{3}{|l|}{ Age at Menarche } \\
\hline$\leq 12$ years & $372(44.0)$ & $658(44.0)$ \\
\hline$>12$ years & $473(56.0)$ & $837(56.0)$ \\
\hline missing & 10 & 13 \\
\hline \multicolumn{3}{|l|}{ Parity } \\
\hline Nulliparous & $119(13.9)$ & $198(13.1)$ \\
\hline Parous & $736(86.1)$ & $1310(86.9)$ \\
\hline \multicolumn{3}{|c|}{ Age at First Birth (among parous women only) } \\
\hline$\leq 23$ years & $242(32.9)$ & $437(33.4)$ \\
\hline $23-27$ years & $241(32.7)$ & $430(32.9)$ \\
\hline$\geq 27$ years & $253(34.4)$ & $442(33.8)$ \\
\hline missing & 0 & 1 \\
\hline \multicolumn{3}{|c|}{ Lactaction (among parous women only) } \\
\hline Never & $462(62.8)$ & $830(63.4)$ \\
\hline Ever & $274(37.2)$ & 480 (36.6) \\
\hline \multicolumn{3}{|l|}{ Tumor Stage } \\
\hline In Situ & $104(12.2)$ & 235 (15.6) \\
\hline Invasive & 751 (87.8) & $1273(84.4)$ \\
\hline \multicolumn{3}{|l|}{ ER Status } \\
\hline Positive & $478(76.2)$ & 726 (73.3) \\
\hline Negative & 149 (23.8) & 264 (26.7) \\
\hline missing & 228 & 518 \\
\hline \multicolumn{3}{|l|}{ PR Status } \\
\hline Positive & 399 (63.6) & 635 (64.1) \\
\hline Negative & 228 (36.3) & 355 (35.9) \\
\hline missing & 228 & 518 \\
\hline
\end{tabular}

methylation status between lactation or parity and ER + PR+ breast cancer (Additional file 1: Tables S3 and S4).

\section{Discussion}

Our study showed that reproductive characteristics, established risk factors for breast cancer, were associated with methylation sites in tumor tissue of women with breast cancer. Our findings lend support to our hypothesis that reproductive characteristics may be differentially associated with breast cancer based on the methylation status of the tumor.

Specifically, we observed higher odds of methylation for $B R C A 1$ in association with late age at first birth. BRCA1 is a tumor suppressor gene, and higher odds of methylation levels are associated with reduced expression in The Cancer Genome Atlas (TCGA) data. [27] Conversely, we observed lower odds of tumor methylation of CDH1 and TWIST1, both involved in epithelial-mesenchymal transition (EMT), 
Table 2 Age-adjusted Odds ratios (ORs) and 95\% confidence intervals (Cls) for the association between age at menarche and breast cancer defined by gene-specific promoter methylation (comparing case women with and without methylated breast cancer [ $\mathrm{N}=$ 855]), Long Island Breast Cancer Study Project

\begin{tabular}{|c|c|c|c|c|c|c|}
\hline \multirow[b]{2}{*}{ Gene promoter } & \multicolumn{3}{|l|}{ Over 12 years of age } & \multicolumn{3}{|l|}{12 years of age or younger } \\
\hline & Methylated/Unmethylated & OR & $95 \% \mathrm{Cl}$ & Methylated/Unmethylated & OR & $95 \% \mathrm{Cl}$ \\
\hline$A P C$ & $207 / 235$ & 1.00 & reference & $177 / 172$ & 1.17 & $0.89-1.55$ \\
\hline BRCA1 & $290 / 180$ & 1.00 & reference & $208 / 163$ & 0.79 & $0.60-1.04$ \\
\hline $\mathrm{CDH} 1$ & $23 / 403$ & 1.00 & reference & 20/311 & 1.13 & $0.61-2.09$ \\
\hline CCND2 & $83 / 343$ & 1.00 & reference & $65 / 266$ & 1.03 & $0.71-1.48$ \\
\hline DAPK & $61 / 365$ & 1.00 & reference & $46 / 285$ & 0.98 & $0.65-1.49$ \\
\hline ESR1 & $215 / 251$ & 1.00 & reference & $162 / 205$ & 0.92 & $0.70-1.22$ \\
\hline GSTP1 & $115 / 311$ & 1.00 & reference & $97 / 234$ & 1.12 & $0.82-1.54$ \\
\hline HIN & $268 / 158$ & 1.00 & reference & $208 / 123$ & 1.00 & $0.74-1.34$ \\
\hline P16 & $14 / 413$ & 1.00 & reference & $16 / 325$ & 1.45 & $0.70-3.02$ \\
\hline$P G R$ & $50 / 420$ & 1.00 & reference & $49 / 322$ & 1.28 & $0.84-1.94$ \\
\hline$R A R B$ & $123 / 303$ & 1.00 & reference & $85 / 246$ & 0.86 & $0.62-1.18$ \\
\hline RASSFIA & $363 / 63$ & 1.00 & reference & $281 / 50$ & 0.98 & $0.66-1.47$ \\
\hline TWIST1 & $62 / 364$ & 1.00 & reference & $53 / 278$ & 1.13 & $0.76-1.69$ \\
\hline
\end{tabular}

in association with late age at first birth. E-cadherin protein is encoded by CDH1 (16q22.1) and mediates hemophilic cell-cell adhesion between neighboring cells. [28] Loss of Ecadherin is considered a fundamental event in EMT, [29] and is associated with invasion and metastasis of breast cancer cells. [30] A priori, we hypothesized that late age at first birth would be associated with higher odds of $C D H 1$ promoter methylation in breast tumor tissue, thereby resulting in gene silencing and reduced expression of the Ecadherin protein. Our finding of a monotonic reduction in breast tumor $\mathrm{CDH} 1$ methylation with increasing age at first birth is counter to our hypothesis and could be due to chance with less than 10 methylated cases in each age stratum. Further, while DNA methylation of $\mathrm{CDH} 1$ is an important mechanism for inhibition of E-cadherin protein expression in breast cancer cell lines, [31, 32] studies examining methylation of primary breast cancer tissues remain limited and are conflicting. [33, 34]

Twist-related protein 1 is a basic helix-loop-helix transcription factors implicated in cell lineage determination

Table 3 Age-adjusted Odds ratios (ORs) and 95\% confidence intervals (Cls) for the association between age at first birth and breast cancer as defined by gene-specific promoter methylation (comparing parous case women with and without methylated breast cancer $[N=736]$ ), Long Island Breast Cancer Study Project

\begin{tabular}{|c|c|c|c|c|c|c|c|c|c|}
\hline \multirow[b]{2}{*}{$\begin{array}{l}\text { Gene } \\
\text { promoter }\end{array}$} & \multicolumn{3}{|l|}{$\leq 23$ years } & \multicolumn{3}{|c|}{ 23-27 years of age } & \multicolumn{3}{|l|}{$\geq 27$ years } \\
\hline & $\begin{array}{l}\text { Methylated/ } \\
\text { Unmethylated }\end{array}$ & OR & $95 \% \mathrm{Cl}$ & $\begin{array}{l}\text { Methylated/ } \\
\text { Unmethylated }\end{array}$ & OR & $95 \% \mathrm{Cl}$ & $\begin{array}{l}\text { Methylated/ } \\
\text { Unmethylated }\end{array}$ & OR & $95 \% \mathrm{Cl}$ \\
\hline$\overline{A P C}$ & $105 / 120$ & 1.00 & reference & $108 / 122$ & 1.08 & $0.90-1.30$ & $118 / 115$ & 1.18 & $0.81-1.70$ \\
\hline BRCA1 & $130 / 110$ & 1.00 & reference & $135 / 106$ & 1.28 & $1.07-1.53$ & $166 / 86$ & 1.63 & $1.14-2.35$ \\
\hline $\mathrm{CDH} 1$ & $20 / 209$ & 1.00 & reference & 9/199 & 0.66 & $0.44-1.00$ & $10 / 220$ & 0.44 & $0.20-0.99$ \\
\hline CCND2 & $45 / 184$ & 1.00 & reference & $44 / 164$ & 1.00 & $0.79-1.26$ & $46 / 184$ & 1.00 & $0.63-1.59$ \\
\hline DAPK & $38 / 191$ & 1.00 & reference & $32 / 176$ & 0.78 & $0.60-1.02$ & $25 / 205$ & 0.61 & $0.36-1.04$ \\
\hline ESR1 & $108 / 130$ & 1.00 & reference & $117 / 122$ & 0.94 & $0.79-1.12$ & $105 / 143$ & 0.88 & $0.62-1.26$ \\
\hline GSTP1 & $67 / 162$ & 1.00 & reference & $59 / 149$ & 0.90 & $0.74-1.11$ & $58 / 172$ & 0.82 & $0.54-1.23$ \\
\hline HIN & $150 / 79$ & 1.00 & reference & $129 / 79$ & 0.87 & $0.72-1.05$ & $135 / 95$ & 0.75 & $0.51-1.09$ \\
\hline P16 & $13 / 205$ & 1.00 & reference & $7 / 216$ & 0.69 & $0.42-1.11$ & $7 / 219$ & 0.47 & $0.18-1.24$ \\
\hline$P G R$ & $27 / 213$ & 1.00 & reference & $25 / 216$ & 1.14 & $0.86-1.49$ & $35 / 217$ & 1.29 & $0.75-2.23$ \\
\hline$R A R B$ & $59 / 170$ & 1.00 & reference & $58 / 150$ & 1.08 & $0.88-1.32$ & $66 / 164$ & 1.16 & $0.77-1.75$ \\
\hline RASSFIA & $188 / 41$ & 1.00 & reference & $178 / 30$ & 1.21 & $0.94-1.56$ & $200 / 30$ & 1.46 & $0.88-2.44$ \\
\hline TWIST1 & $44 / 185$ & 1.00 & reference & $30 / 178$ & 0.69 & $0.53-0.91$ & $24 / 206$ & 0.48 & $0.28-0.82$ \\
\hline
\end{tabular}


Table 4 Age-adjusted Odds ratios (ORs) and 95\% confidence intervals (Cls) for the association between lactation practices and breast cancer as defined by gene-specific promoter methylation in breast tumor tissue (comparing parous case women with and without methylated breast cancer [N = 736]), Long Island Breast Cancer Study Project

\begin{tabular}{|c|c|c|c|c|c|c|}
\hline \multirow[b]{2}{*}{ Gene promoter } & \multicolumn{3}{|l|}{ Any Lactation } & \multicolumn{3}{|l|}{ No Lactation } \\
\hline & Methylated/ Unmethylated & OR & $95 \% \mathrm{Cl}$ & Methylated/ Unmethylated & OR & $95 \% \mathrm{Cl}$ \\
\hline$\overline{A P C}$ & $113 / 146$ & 1.00 & reference & $218 / 211$ & 1.33 & $0.97-1.81$ \\
\hline BRCA1 & $166 / 107$ & 1.00 & reference & $265 / 195$ & 0.89 & $0.66-1.21$ \\
\hline $\mathrm{CDH} 1$ & $19 / 228$ & 1.00 & reference & $20 / 400$ & 0.60 & $0.31-1.15$ \\
\hline CCND2 & $51 / 196$ & 1.00 & reference & $84 / 336$ & 0.96 & $0.65-1.42$ \\
\hline DAPK & $41 / 206$ & 1.00 & reference & $54 / 366$ & 0.74 & $0.47-1.15$ \\
\hline ESR1 & $117 / 151$ & 1.00 & reference & $213 / 244$ & 1.13 & $0.83-1.53$ \\
\hline GSTP1 & $71 / 176$ & 1.00 & reference & $113 / 307$ & 0.91 & $0.64-1.30$ \\
\hline HIN & $160 / 87$ & 1.00 & reference & $254 / 166$ & 0.83 & $0.60-1.16$ \\
\hline P16 & $10 / 243$ & 1.00 & reference & $17 / 397$ & 1.05 & $0.47-2.34$ \\
\hline$P G R$ & $41 / 232$ & 1.00 & reference & $46 / 414$ & 0.63 & $0.40-0.99$ \\
\hline$R A R B$ & 70/177 & 1.00 & reference & $113 / 307$ & 0.93 & $0.65-1.32$ \\
\hline RASSFIA & $214 / 33$ & 1.00 & reference & $352 / 68$ & 0.79 & $0.51-1.25$ \\
\hline TWIST1 & $37 / 210$ & 1.00 & reference & $61 / 359$ & 0.96 & $0.62-1.50$ \\
\hline
\end{tabular}

and differentiation. Our observation of reduced methylation of TWIST1 with late age at first birth is consistent with our hypothesis of oncogenic activation. Overexpression of Twist or methylation of its promoter is common in metastatic carcinomas, including breast. [35] Thus, age at first birth may both increase methylation of oncogenes and repress methylation of tumor suppressor genes, which may have implications for both gene expression and cell functioning.
We also observed that among parous women who did not breastfeed, the odds of methylation of the PGR gene promoter in breast cancer was reduced. Decreased expression of $P G R$, a steroid hormone receptor that helps to maintain normal cell growth and regulation, also plays a role in breast carcinogenesis; although links between $P G R$ promoter methylation and protein expression are weak and unlikely to represent the predominant mechanism of receptor silencing. [36]

Table 5 Age-adjusted Odds ratios (ORs) and 95\% confidence intervals (Cls) for the association between parity and breast cancer as defined by gene-specific promoter methylation (comparing case women with and without methylated breast cancer [N = 855]), Long Island Breast Cancer Study Project

\begin{tabular}{|c|c|c|c|c|c|c|}
\hline \multirow[b]{2}{*}{ Gene promoter } & \multicolumn{3}{|l|}{ Parous } & \multicolumn{3}{|l|}{ Nulliparous } \\
\hline & Methylated/Unmethylated & OR & $95 \% \mathrm{Cl}$ & Methylated/Unmethylated & OR & $95 \% \mathrm{Cl}$ \\
\hline$A P C$ & $331 / 357$ & 1.00 & reference & $56 / 56$ & 1.10 & $0.74-1.64$ \\
\hline$B R C A 1$ & $431 / 302$ & 1.00 & reference & $73 / 45$ & 1.11 & $0.75-1.66$ \\
\hline $\mathrm{CDH1}$ & $39 / 629$ & 1.00 & reference & $5 / 93$ & 0.87 & $0.33-2.27$ \\
\hline CCND2 & $135 / 532$ & 1.00 & reference & $15 / 83$ & 0.75 & $0.42-1.35$ \\
\hline DAPK & $95 / 572$ & 1.00 & reference & $13 / 85$ & 0.97 & $0.52-1.82$ \\
\hline ESR1 & $330 / 395$ & 1.00 & reference & $53 / 65$ & 0.98 & $0.66-1.45$ \\
\hline GSTP1 & $184 / 483$ & 1.00 & reference & $29 / 69$ & 1.11 & $0.69-1.76$ \\
\hline HIN & $414 / 253$ & 1.00 & reference & $67 / 31$ & 1.32 & $0.84-2.08$ \\
\hline P16 & $27 / 640$ & 1.00 & reference & $3 / 107$ & \multicolumn{2}{|c|}{ not estimated ${ }^{a}$} \\
\hline$P G R$ & $87 / 646$ & 1.00 & reference & $15 / 103$ & 1.07 & $0.60-1.93$ \\
\hline$R A R B$ & $183 / 484$ & 1.00 & reference & $28 / 70$ & 1.08 & $0.68-1.74$ \\
\hline RASSFIA & $566 / 101$ & 1.00 & reference & $86 / 12$ & 1.34 & $0.70-2.55$ \\
\hline TWISTI & $98 / 569$ & 1.00 & reference & $18 / 80$ & 1.36 & $0.78-2.38$ \\
\hline
\end{tabular}

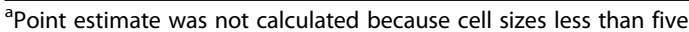


In our population-based sample, we considered genespecific methylation with reproductive characteristics, and explored heterogeneity by hormone receptor subtype (ER + PR+ vs. all others), as locus-specific methylation may be particularly associated with certain breast cancer tumor subtypes. [37, 38] We found that women with early age at menarche and promoter RASSF1A methylation had lower odds of developing ER + PR+ breast cancer than women with unmethylated RASSF1A promoters. Ras association domain-containing protein 1 is a protein that, in humans, is encoded by the RASSF1 gene, a putative tumor suppressor, involved in cell cycle control [14] and breast carcinogenesis. [39] Thus, our findings are contrary to our biologically driven hypothesis of enhanced odds of ER + $\mathrm{PR}+$ breast cancer with early menarche and RASSF1A promoter methylation. They further conflict with a previous report of a positive correlation between RASSF1A methylation levels and percentage of cancer cells expressing ER and PR. [40]

We also observed that the odds of being an ER + PR+ breast cancer case was enhanced among women with late age at first birth ( $>27$ years) in the presence of unmethylated $B R C A 1$ promoter. As described above, $B R C A 1$ is a tumor suppressor and its methylation has been associated with loss of BRCA1 expression. The triple-negative subtype (ER-/PR-/HER2-) is associated with BRCA1 germline and somatic mutations [41] and our observation of a more than two-fold increase in odds of ER + PR+ breast cancer (vs. any ER- or PR-) among women jointly characterized as having late age at first pregnancy and unmethylated $B R C A 1$ promoter is consistent with these findings.

Strengths of our study include our population-based design. This approach enhances generalizability and facilitates quantification of any study bias due to subject selection. We also used a detailed method to assess reproductive characteristics, which reduces the likelihood of measurement error. In addition, our case-case approach rules out differential recall bias given that both the "case" and "comparison" groups had breast cancer. Limitations of our study include that we were unable to obtain archived tumor tissue for all LIBCSP case participants, which may result in selection bias as smaller tumors would be less likely to have sufficient tumor tissue available for the methylation assays. However, we observed minimal differences among case women with information on methylation status and all LIBCSP cases. Also, classification of methylation status is not universally defined and our cutoff of $4 \%$ may not be biologically relevant for all the genes assessed. We used a panel of a priori genes, [14] and thus, we cannot discount other methylation sites which could be relevant to reproductive characteristics and breast cancer. Given that biological significance is often $5^{\prime}-\mathrm{C}-$ phosphate- $\mathrm{G}-3^{\prime}$ (CpG) or region-specific, our lack of expected results for $C D H 1$ and RASSF1A may be related to not hitting on the 'right' CpGs for these genes. We did not adjust for multiple comparisons, because of the limited number of genes considered and because associations were driven by biologically plausible hypotheses. However, we recognize that some of these associations may be due to chance given the low prevalence of methylation, in some instances, and imprecise estimates. Finally, a potential limitation of the study is that women are now having their children at an older age than the mean/median experienced by the LIBCSP women. However, we anticipate that the biologic mechanisms underlying the association between late age at first birth, methylation, and cancer would be consistent despite a shift in age distribution. Our findings help to provide proof of principle for our novel hypothesis, and future studies could examine this issue with points further along a potential dose response curve.

\section{Conclusions}

Among a large population-based sample, age at first birth and lactation were differentially associated with breast cancer based on the DNA methylation status of the tumor. While our results require confirmation in larger studies with robust gene coverage, they suggest that reproductive history may associate with gene promotors implicated in breast carcinogenesis which could be biomarkers of risk or molecular targets for prevention.

\section{Supplementary information}

The online version of this article (https://doi.org/10.1186/s12885-019-6120-4) contains supplementary material, which is available to authorized users.

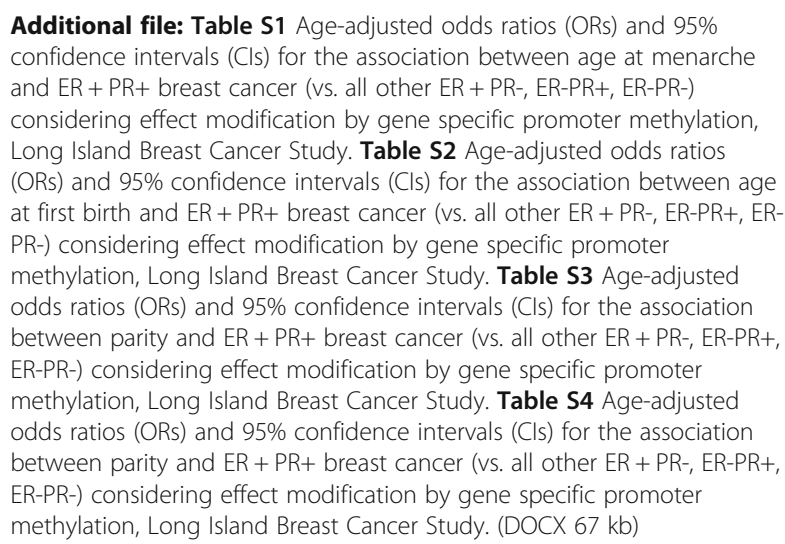

\section{Abbreviations}

APC: Adenomatous polyposis coli; BRCA1: Breast cancer 1, early onset; CCND2: Cyclin D2; CDH1: E-Cadherin; CDKN2A: Cyclin-dependent kinase inhibitor 2A; Cl: Confidence interval; CpG: 5'-C - phosphate-G-3';

DAG: Directed acyclic graph; DAPK1: Death-associated protein kinase 1; EMT: Epithelial-mesenchymal transition; ER: Estrogen receptor; ESR1: Estrogen receptor 1; GSTP1: Glutathione S-transferase pi 1; HER2: Human epidermal growth factor receptor 2; HIN1: Secretoglobin, family 3A, member 1;

LIBCSP: Long Island Breast Cancer Study Project; MSP: Methylation specific; NY: New York; OR: Odds ratio; PCR: Polymerase chain reaction;

PGR: Progesterone gene receptor; PR: Progesterone receptor; $R A R \beta$ : Retinoic 
acid receptor beta; RASSF1A: Ras association domain family member 1; TCGA: The Cancer Genome Atlas; TWIST1: Twist homolog 1

\section{Acknowledgements \\ Not applicable.}

\section{Authors' contributions}

LEM, KC, and MDG conceptualized the research question. MDG, JC, RMS, YHC, SS, MBT, SLT, and AIN conducted the research. LJC, LEM, and AJW analyzed data. LJC, LEM, and MDG wrote the paper. MDG, JC, LEM, and LJC had primary responsibility for final content. All authors aided in data interpretation, reviewed draft manuscripts, and read and approved the final manuscript.

\section{Funding}

This work was supported in part by grants from the National Institutes of Health (Grant numbers R25CA057726, UO1CA/ES66572, R01CA109753, 3R01CA109753-04S1, P30ES009089) the Department of Defense (Grant number BC972772), and the intramural program of the National Institutes of Health (Grant number Z99 ES99999). The study funders had no role in the design, data acquisition, analyses, or data interpretation of this project.

\section{Availability of data and materials}

The datasets used and/or analysed during the current study are available from the study PI, Dr. Marilie Gammon gammon@unc.edu, on reasonable request.

\section{Ethics approval and consent to participate}

Institutional Review Board approval was obtained by all participating institutions (Columbia University, University of North Carolina Chapel Hill, and Emory University).

\section{Consent for publication}

Not applicable.

\section{Competing interests}

S. Shantakumar is employed at Glaxosmithkline and owns shares. A. Neugut serves as a consultant for Otsuka Pharmaceuticals, Pfizer, Eisai, Hospira, Teva, and United Biosource Corp, and is also a member of the medical advisory board of EHE Intl. No potential conflicts of interest were disclosed by the other authors.

\section{Author details}

${ }^{1}$ Department of Epidemiology, Emory University, Atlanta, GA 30322, USA. 2Department of Epidemiology, University of North Carolina, Chapel Hill, NC 27599, USA. ${ }^{3}$ Epidemiology Branch, National Institute of Environmental Health Science, Research Triangle Park, NC 27709, USA. ${ }^{4}$ Department of Biomedical and Pharmaceutical Sciences, University of Montana, Missoula, MT 59812, USA. ${ }^{5}$ Epidemiology, Real World Evidence and Digital Platforms, Glaxosmithkline, Singapore, Singapore. 'Department of Epidemiology, Columbia University, New York, NY 10032, USA. 'Department of Medicine, Columbia University, New York, NY 10032, USA. ${ }^{8}$ Department of Environmental Health Sciences, Columbia University, New York, NY 10032, USA. ${ }^{9}$ Department of Environmental Medicine and Public Health, Icahn School of Medicine at Mount Sinai, New York, NY 10029, USA. ${ }^{10}$ Department of Pediatrics, Icahn School of Medicine at Mount Sinai, New York, NY 10029, USA. ${ }^{11}$ Department of Oncological Science, Icahn School of Medicine at Mount Sinai, New York, NY 10029, USA.

Received: 2 May 2019 Accepted: 2 September 2019 Published online: 18 September 2019

\section{References}

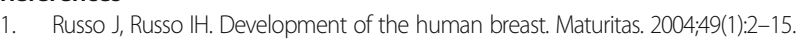

2. Ruder EH, Dorgan JF, Kranz S, Kris-Etherton PM, Hartman TJ. Examining breast cancer growth and lifestyle risk factors: early life, childhood, and adolescence. Clin Breast Cancer. 2008;8(4):334-42.

3. Hankinson SE, Colditz GA, Willett WC. Towards an integrated model for breast cancer etiology: the lifelong interplay of genes, lifestyle, and hormones. Breast Cancer Res. 2004;6(5):213-8.
4. Wu HC, Delgado-Cruzata L, Flom JD, Perrin M, Liao Y, Ferris JS, et al. Repetitive element DNA methylation levels in white blood cell DNA from sisters discordant for breast cancer from the New York site of the breast Cancer family registry. Carcinogenesis. 2012;33(10):1946-52.

5. Virmani AK, Rathi A, Sathyanarayana UG, Padar A, Huang CX, Cunnigham $H T$, et al. Aberrant methylation of the adenomatous polyposis coli (APC) gene promoter 1A in breast and lung carcinomas. Clin Cancer Res. 2001; 7(7):1998-2004.

6. Cho YH, Shen J, Gammon MD, Zhang YJ, Wang Q, Gonzalez K, et al. Prognostic significance of gene-specific promoter hypermethylation in breast cancer patients. Breast Cancer Res Treat. 2012;131(1):197-205.

7. Bollati V, Baccarelli A. Environmental epigenetics. Heredity (Edinb). 2010; 105(1):105-12

8. Cortessis VK, Thomas DC, Levine AJ, Breton CV, Mack TM, Siegmund KD, et al. Environmental epigenetics: prospects for studying epigenetic mediation of exposure-response relationships. Hum Genet. 2012;131(10):1565-89.

9. Tao MH, Marian C, Shields PG, Potischman N, Nie J, Krishnan SS, et al. Exposures in early life: associations with DNA promoter methylation in breast tumors. J Dev Orig Health Dis. 2013;4(2):182-90.

10. Gammon MD, Neugut Al, Santella RM, Teitelbaum SL, Britton JA, Terry MB, et al. The Long Island breast Cancer study project: description of a multiinstitutional collaboration to identify environmental risk factors for breast cancer. Breast Cancer Res Treat. 2002;74(3):235-54.

11. Belli RF. The structure of autobiographical memory and the event history calendar: potential improvements in the quality of retrospective reports in surveys. Memory. 1998;6(4):383-406.

12. Shantakumar S, Terry MB, Teitelbaum SL, Britton JA, Millikan RC, Moorman PG, et al. Reproductive factors and breast cancer risk among older women. Breast Cancer Res Treat. 2007;102(3):365-74.

13. Rossner P Jr, Gammon MD, Zhang YJ, Terry MB, Hibshoosh H, Memeo L, et al. Mutations in p53, p53 protein overexpression and breast cancer survival. J Cell Mol Med. 2009;13(9b):3847-57.

14. Xu X, Gammon MD, Jefferson E, Zhang Y, Cho YH, Wetmur JG, et al. The influence of one-carbon metabolism on gene promoter methylation in a population-based breast cancer study. Epigenetics. 2011;6(11):1276-83.

15. Xu X, Gammon MD, Zhang Y, Bestor TH, Zeisel SH, Wetmur JG, et al. BRCA1 promoter methylation is associated with increased mortality among women with breast cancer. Breast Cancer Res Treat. 2009;115(2):397-404.

16. Xu X, Gammon MD, Hernandez-Vargas H, Herceg Z, Wetmur JG, Teitelbaum SL, et al. DNA methylation in peripheral blood measured by LUMA is associated with breast cancer in a population-based study. FASEB J. 2012;26(6):2657-66.

17. Liu ZJ, Maekawa M, Horii T, Morita M. The multiple promoter methylation profile of PR gene and ERalpha gene in tumor cell lines. Life Sci. 2003; 73(15):1963-72.

18. Gibson UE, Heid CA, Williams PM. A novel method for real time quantitative RT-PCR. Genome Res. 1996;6(10):995-1001.

19. Livak KJ, Schmittgen TD. Analysis of relative gene expression data using real-time quantitative PCR and the 2(-Delta Delta C(T)) method. Methods. 2001;25(4):402-8.

20. Eads CA, Danenberg KD, Kawakami K, Saltz LB, Blake C, Shibata D, et al. MethyLight: a high-throughput assay to measure DNA methylation. Nucleic Acids Res. 2000;28(8):E32.

21. Ogino S, Kawasaki T, Brahmandam M, Cantor M, Kirkner GJ, Spiegelman D, et al. Precision and performance characteristics of bisulfite conversion and real-time PCR (MethyLight) for quantitative DNA methylation analysis. J Mol Diagn. 2006;8(2):209-17.

22. Begg CB, Zhang ZF. Statistical analysis of molecular epidemiology studies employing case-series. Cancer Epidemiol Biomark Prev. 1994;3(2):173-5.

23. Collaborative Group on Hormonal Factors in Breast Cancer. Breast cancer and breastfeeding: collaborative reanalysis of individual data from 47 epidemiological studies in 30 countries, including 50302 women with breast cancer and 96973 women without the disease. Lancet. 2002;360(9328):187-95.

24. Kelsey JL, Gammon MD, John EM. Reproductive factors and breast cancer. Epidemiol Rev. 1993;15(1):36-47.

25. Greenland S, Brumback B. An overview of relations among causal modelling methods. Int J Epidemiol. 2002;31(5):1030-7.

26. Greenland S. Modeling and variable selection in epidemiologic analysis. Am J Public Health. 1989:79(3):340-9.

27. Niwa Y, Oyama T, Nakajima T. BRCA1 expression status in relation to DNA methylation of the BRCA1 promoter region in sporadic breast cancers. Jpn J Cancer Res. 2000;91(5):519-26. 
28. van Roy F, Berx G. The cell-cell adhesion molecule E-cadherin. Cell Mol Life Sci. 2008;65(23):3756-88.

29. Yamada S, Pokutta S, Drees F, Weis WI, Nelson WJ. Deconstructing the cadherin-catenin-actin complex. Cell. 2005;123(5):889-901.

30. Andrews JL, Kim AC, Hens JR. The role and function of cadherins in the mammary gland. Breast Cancer Res. 2012;14(1):203.

31. Benton G, Crooke E, George J. Laminin-1 induces E-cadherin expression in 3-dimensional cultured breast cancer cells by inhibiting DNA methyltransferase 1 and reversing promoter methylation status. FASEB J. 2009;23(11):3884-95.

32. Cheng CW, Wu PE, Yu JC, Huang CS, Yue CT, Wu CW, et al. Mechanisms of inactivation of E-cadherin in breast carcinoma: modification of the two-hit hypothesis of tumor suppressor gene. Oncogene. 2001;20(29):3814-23.

33. Liu J, Sun X, Qin S, Wang H, Du N, Li Y, et al. CDH1 promoter methylation correlates with decreased gene expression and poor prognosis in patients with breast cancer. Oncol Lett. 2016;11(4):2635-43.

34. Ciriello G, Gatza ML, Beck AH, Wilkerson MD, Rhie SK, Pastore A, et al. Comprehensive molecular portraits of invasive lobular breast Cancer. Cell. 2015;163(2):506-19.

35. Martin TA, Goyal A, Watkins G, Jiang WG. Expression of the transcription factors snail, slug, and twist and their clinical significance in human breast cancer. Ann Surg Oncol. 2005;12(6):488-96.

36. Gaudet MM, Campan M, Figueroa JD, Yang XR, Lissowska J, Peplonska B, et al. DNA hypermethylation of ESR1 and PGR in breast cancer: pathologic and epidemiologic associations. Cancer Epidemiol Biomark Prev. 2009;18(11):3036-43.

37. Avraham A, Cho SS, Uhlmann R, Polak ML, Sandbank J, Karni T, et al. Tissue specific DNA methylation in normal human breast epithelium and in breast cancer. PLoS One. 2014;9(3):e91805.

38. Bardowell SA, Parker J, Fan C, Crandell J, Perou CM, Swift-Scanlan T. Differential methylation relative to breast cancer subtype and matched normal tissue reveals distinct patterns. Breast Cancer Res Treat. 2013;142(2):365-80.

39. Hesson LB, Cooper WN, Latif F. The role of RASSF1A methylation in cancer. Dis Markers. 2007;23(1-2):73-87.

40. Kajabova V, Smolkova B, Zmetakova I, Sebova K, Krivulcik T, Bella V, et al. RASSF1A promoter methylation levels positively correlate with estrogen receptor expression in breast Cancer patients. Transl Oncol. 2013;6(3):297-304.

41. Lee E, McKean-Cowdin R, Ma H, Spicer DV, Van Den Berg D, Bernstein L, et al. Characteristics of triple-negative breast cancer in patients with a BRCA1 mutation: results from a population-based study of young women. J Clin Oncol. 2011;29(33):4373-80.

\section{Publisher's Note}

Springer Nature remains neutral with regard to jurisdictional claims in published maps and institutional affiliations.

Ready to submit your research? Choose BMC and benefit from:

- fast, convenient online submission

- thorough peer review by experienced researchers in your field

- rapid publication on acceptance

- support for research data, including large and complex data types

- gold Open Access which fosters wider collaboration and increased citations

- maximum visibility for your research: over $100 \mathrm{M}$ website views per year

At $\mathrm{BMC}$, research is always in progress.

Learn more biomedcentral.com/submissions 